\title{
Psychosocial Aspects Regarding Student-Teacher Relationship in the Lesson of Physical Education
}

\author{
Lupu Gabriel ${ }^{1 *}$ \\ 1"Vasile Alecsandri" University of Bacău, 157, Calea Mărășești, 600115, Romania
}

Keywords: teacher, student, relationships psychosocial, physical education lesson

\begin{abstract}
Knowledge and adjustment relations in the psychosocial sports groups should be a permanent concern of those who seek to obtain performance (coaches, teachers, psychologists, technical staff, etc.), by exploiting all the factors that contribute to obtain it. We approached this issue because we believe that the relations established between students on one hand and between teachers and students on the other hand within the collective of students and representative sports teams are very complex and insufficiently studied. Based on the dramatic and conflictual circumstances identified, one can conceive, direct and apply in practice (at the desk or directly on the ground) a number of shares stressful and / or actions charging the emotional through which to try reducing tensions, diminishing and psychosocial conflicts rebalancing construction of a collective class or representative teams of school sports games.
\end{abstract}

\section{Introduction}

The sport teacher needs to have the capacity to know to control himself, to wait and delay when taking some decisions which can hurt the human beeing, the necesity to trust in his own forces and to have a greater trust in the forces of those who teaches (Mitra \& Dragoş, 1980).

Knowledge and adjustment of the psychosocial relationships within the sport groups should represent a permanent concern of those trying to obtain the performance (coaches, professors, psychologists, technical staff and so on), by using all factors that concur to obtain the performance. As the performance sports develop and the worldwide requirements increase, the psychological and social factors become more and more important.

The human relations are so many and variate. When peoples interact, each controls a segment from the other's activity (Newcomb, Turner, \& Converse, 1965).

The biological component consists of the physiological and somatic capacity of the athlete, the psychological one represents the personality with aspirations, will, self-control, creativity, ideals, and the social one is related to education, 
culture and human relations.

The satisfactory and performance levels are dependent of the cohesion of the group (students and / or trainers) and this imposes deep knowledge of the psychobehavioural nuances (Ștefan, 2005).

In sportive games, the collaboration and rivalry acquire different dimensions as opposed to individual games because, inside the team, which is not only an arithmetic mean of its individuals, the inner relations are not always coordinated synergistically (Nicu, 1993).

Students' personality is identifiable by presence and efficiency that characterizes a certain moment. Through psychological analysis, we are able to seize its dimension, spread, period, and practical effectiveness in the adjustment to the effort during the physical education lesson or during the trainings in case of the representative sport teams.

All these belong to a student / athlete (actual) and, thus, are inherent for the student's person (personality), that takes a certain place in the sport performance. The detected phenomena, and the analyzed personality factors are personal spontaneous feelings of the athlete under study. The performance capacity of the sport teams may be increased if, along with the increase of the physical performance of the athletes, increase of the resilience to effort, original match schemes and strategies, we shall also consider the syntality of the player teams.

Every student (player) represents a personality, and welding a team means to set-up connections between the personalities of the players composing the team (Lupu, 2010). Here is a new dimension, less studied and less applied, in the team sport games.

\section{Material and methods}

This paper aims to identify the interpersonal relationships within the collective of students and / or representative teams sports games and also of possibilities to improve their efficiency in order to optimize physical education lessons or increase desire for victory and emulation.

Our hypothesis is as follows: knowing the psycho-social relations between the students on one side and students-teacher on the other side, one can optimize the sympathy and mutual trust feelings, as opposed to those of dislikes, distrust and disregard.

The research methods used were: the bibliographical study, the directly and indirectly observation method, and the survey method.

The study was performed between November 2014 and May 2015 and it involved teams of gymnasium students within the National College „Nicu Ganea” of Fălticeni and the cooperation with the education staff, such as: Professor Mihaela Togoe - CSA „Steaua” Bucharest, professor of 1st degree Vasile Avramia - CN. „Nicu Ganea” of Fălticeni, professor of 1st degree Ciocan Ionel - CN „Nicu Ganea” of Fălticeni.

The group of students of the class VI B within the National College „Nicu Ganea” of Fălticeni was implicated in the performance of this study. 
The human relations between the students during the physical education lessons were investigated and construed in the light of sociometry.

In order to investigate the psychosocial relations, I have selected the male component of the class VI and I have implemented the Sociometric quiz (ColibabaEvuleţ \& Bota, 1998), with 14 items, that helped to determine: the location, the status of a student in the human relations field (leader, popular, isolated, ignored, rejected, etc.); the global psychosocial structure of the class team and of the subgroups in the class team; various influence centers; class perception about a certain member; group cohesion, etc., as well as the Sympathy / antipathy relations quiz towards the education staff and options to improve the physical education lesson.

\section{Results and Discussions}

The options were recorded in a double input table (sociomatrix), where the students were recorded on vertical and horizontal plans, and the relations between them with (+) for attractions and (-) for rejections.

To build the sociomatrix, the answers to questions from 1 to 7 of the quiz I, regarding the preferences and rejections of each and every student, were considered.

Table 1. Sociomatrix of the male group, class VI B

\begin{tabular}{llllllllllllll}
\hline & A.I & A.R & B.N & E.F & L.A & M.G & O.I & P.A & P.V & R.R & S.F & U.M & Z.G \\
\hline A.I. & & -1 & +1 & & -2 & & +2 & -2 & & $+1-2$ & -1 & -1 & \\
A.R. & -2 & & & +2 & +1 & +1 & +2 & -2 & +1 & -2 & +1 & -2 & \\
B.N & +2 & -1 & & +1 & -2 & +2 & +2 & -2 & & -1 & & -1 & \\
E.F & & -3 & & & -1 & -1 & +3 & -2 & +1 & $-1+1$ & & -1 & \\
L.A & & -3 & & +2 & & +1 & +1 & -3 & +1 & +1 & & -3 & \\
M.G & -1 & -2 & -1 & +2 & & & +3 & & -1 & +1 & -1 & -3 & \\
O.I & & -1 & +2 & & -1 & +1 & & -3 & -1 & $+1-2$ & & -1 & \\
P.A & -1 & -1 & & +1 & -2 & +3 & +2 & & & $+1-1$ & & & \\
P.V & -1 & -1 & & +1 & -2 & & +2 & & & $+1-2$ & +1 & -2 & \\
R.R & & -3 & & +1 & & & +3 & & & & -3 & -3 & \\
S.F & & -2 & & -2 & & +1 & +2 & -1 & +1 & -1 & & -1 & -2 \\
U.M & -1 & -1 & & +2 & -2 & +1 & +1 & & & & & & \\
Z.G & -1 & & -2 & & -2 & +1 & +3 & -2 & & & -2 & +1 & \\
\hline
\end{tabular}

Based on the sociogram above, we have built a summary table that includes the number of attractions / rejections for each and every student.

As one may notice in the summary sociomatrix shown, at the male students' level of the class VI B we have: students for which only attraction relations were recorded (without rejections): O.I; students for which only rejection relations were recorded (without attractions): A.R, PA, Z.G; students for which a higher number of attractions and less number of rejections were recorded: EF, M.G.; students for which a lower number of attractions and higher number of rejections were 
recorded: A.I., L.A., U.M; and students who recorded an equal number of attractions and rejections: B.N.

Table 2. Summary matrix of attractions and rejections

\begin{tabular}{cccc}
\hline Nume & Atracții(A) & Respingeri(R) & Total(A-R) \\
\hline A.I. & 2 & 7 & -5 \\
A.R. & 0 & 19 & -19 \\
B.N & 3 & 3 & 0 \\
E.F & 12 & 2 & 10 \\
L.A & 1 & 14 & -13 \\
M.G & 11 & 1 & 10 \\
O.I & 26 & 0 & 26 \\
P.A & 0 & 17 & -17 \\
P.V & 4 & 2 & 2 \\
R.R & 2 & 7 & -5 \\
S.F & 2 & 7 & -5 \\
U.M & 1 & 18 & -17 \\
Z.G. & 0 & 2 & -2 \\
Total & $\mathbf{6 4}$ & $\mathbf{9 9}$ & $-\mathbf{3 5}$ \\
\hline
\end{tabular}

The information supplied by the sociometric test are highly important for the teacher. Based on such information, the position orientation of the relations between students may be achieved, the latent or obvious tensions between them may be explained and the negative relations may be turned into positive relations with educational training valences. From the description of the data above, it results that among the male students there are mutual sympathies and antipathies, where some of the subjects receive the attraction of most of the others and some of the subjects were rejected by most of colleagues.

A first conclusion that may be drawn while analyzing the above sociomatrices is that at the level of the boys group there is, in general, an animosity, a tensed condition, due to the number of rejections is higher than the number of attractions (64 attractions, 99 rejections), fact that could determine a negative impact in the achievement of the aimed results.

According to the sociograms, an absolute informal leader distinguishes - O.I. (26 attractions, 0 rejections) in the boys group.

Within the male group there is no isolated student (does not vote and it is not voted), although we may state that there are 5 tolerated students: A.R., P.A, Z.G, L.A., U.M., the first three of them not receiving any positive vote, and the next two receiving one positive vote each. Students A.R., U.M., P.A. received the highest number of rejections. The cohesion of students' class is an important purpose for the teacher. The students make an united collectivity when they are animated by the desire and the joy of common effort, when they are focused on achieveing the common tasks and decide altogether on class' issue (Lupu, 2010). 
To the quiz II, question 1 - What qualities do you particularly appreciate at the physical education teacher - the answers were graphically represented, as it follows:

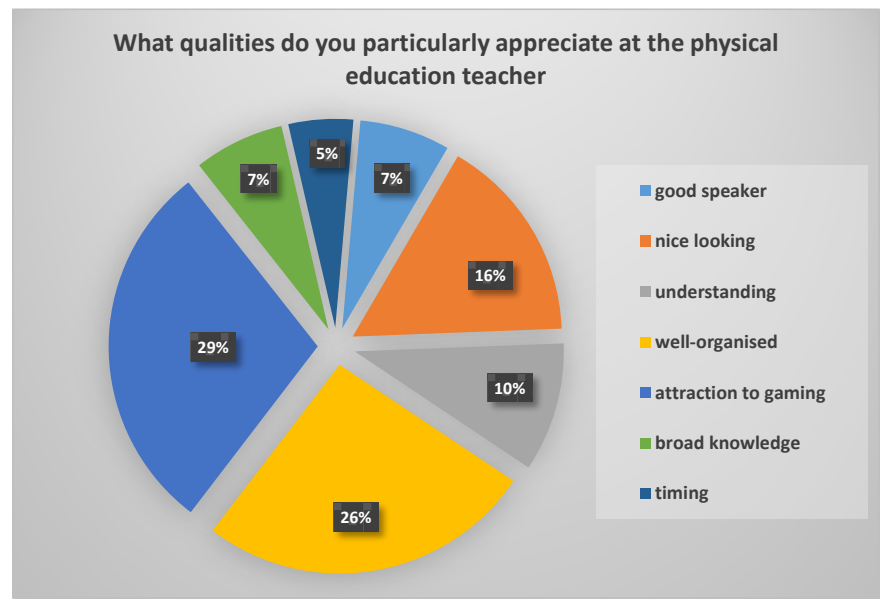

Figure 1. Qualities of the physical education teacher appreciated by the students

One may notice that most of the answers (55\%) are rather equally distributed between the professor's attraction to ludic (29\%) and the skill of good organizer / event initiator (26\%), which is explainable by the age peculiarities of the students in the $\mathrm{VI}^{\text {th }}$ grade.

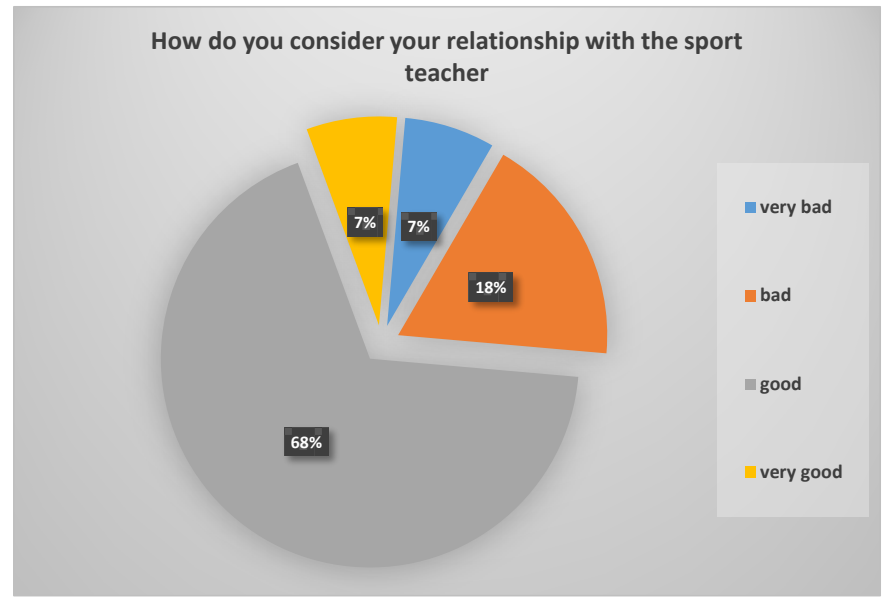

Figure 2. Teacher - students relation

To question 4 - How do you rate your relation with the physical education teacher - most of the students (68\%) consider good the relation with the professor, $18 \%$ consider it bad, and the rest of $14 \%$ is equally distributed on extremes (very bad / very good).

Question 5 - What is your relation to your colleagues during the lesson - 
based on the analysis of the summary data and of the figure 3 , the same conclusion may be drawn, that was analytically derived from the implementation of the quiz I and sociogram interpretation, meaning that at the class level, the relations between the students are not ok.

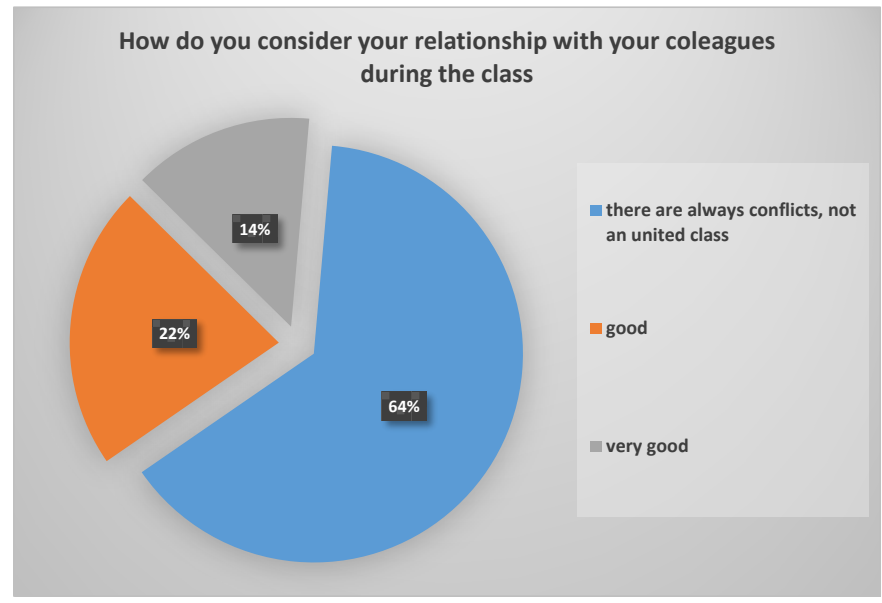

Figure 3. Human relations - students of the $V^{\text {th }}$ grade B

To question 10 - What type of leadership do you prefer from your physical education teacher - almost half of the questioned students declared in favor of a so-called laissez-faire type of leadership (56\%), while 36\% wish to have a democratic leadership, and the rest an autocratic leadership.

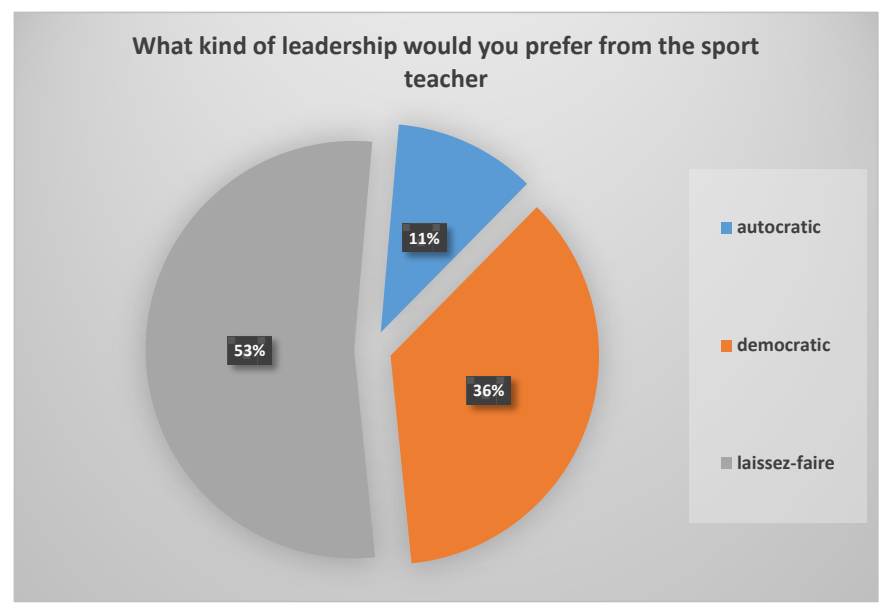

Figure 4. Types of leaderships preferred by the students

\section{Discussions}

In sport activity, the preferential relations can be divided into affective and operational (Rioux \& Chappuis (1999), as cited in Epuran, 2005).

In view of facilitating the settlement of the disciplinary issues, the professor 
may take part to the student's case, is able to express his/her concern to the student in his/her quality of individual, therefore building a relation with the student. This way, the professor is able to help his/her students reflect on their own wishes and plans, also trying to understand their options. In case the student made an irresponsible choice, the teacher may ask him/her: „What do you actually wish for?” „What do you need?” „How would like it to be at school?”

The relationship between the teacher and the student is the main method of educational mediation, of transposing it into a human subjective version. Beyond the actual contents transmitted, in the educational activity it will also matter very much the type of interaction that will settle down between the class of students and the teachers, as well as the teacher's attitude in relating as a group and with each and every student.

The relations between the teacher and the student may be characterized by dimensions such as: conflict, approach and excessive dependency. These are closely related to other variables such as: age, ethnic nature, social status.

Too much "exposure" from the physical education teacher can be embarrassing, and too little can freeze the relations with the students (Pop, 2009).

\section{Conclusions}

Due to the distinct character of the physical education lesson compared to other sciences, one may measure and it is required to measure the human relations in the team in view of identifying a leader, a mediator between the educational staff and the team, who many times is not the same as the „class leader”.

In the contents of the physical education teacher's personality, the love for movement, and the passion for physical education and sport has a significant role. The teacher must convince the students of the need and utility of practicing the physical education, through personal example, and it should be a good specialist and educationalist.

Our assumption is confirmed, as the knowledge of the group's psychosocial environment matters in the management of the relations between the physical education teacher and the student due to it helps stimulating the student in exceeding its own limits, in accepting the team partners, in the wish for victory or in accepting the defeat, and in promoting the fair-play spirit.

\section{References}

1. COLIBABA-EVULET,, D., \& BOTA, I. (1998). Jocuri sportive. Teorie şi

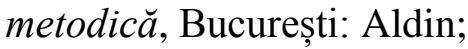

2. EPURAN, M. (2005). Elemente de psihosociologia activităţilor corporale, București: Renaissance;

3. LUPU, G. (2010). Relaţiile psihosociale din cadrul echipelor de jocuri sportive şi optimizarea lor în vederea creşterii capacității de performanţă teza de doctorat, Pitești;

4. MITRA, G., \& DRAGOŞ, A. (1980). Metodica educației fizice școlare, București: Sport-Turism; 
5. NICU, A. (1993). Antrenamentul sportiv modern, București: Editis;

6. NEWCOMB, T.M., TURNER, R.H., \& CONVERSE, P.E. (1965). Social Psychology,, New York: Holt, Rinehart \& Winston;

7. POP, C. (2009). Comunicare şi relaţionare în lecţia de educaţie fizică, Marathon, 2(1), p134-139;

8. ȘTEFAN, I. (2005). Introducere în sociologia educației fizice și sportului, Brașov: Universităţii Transilvania.

\section{Aspecte Psihosociale Privind Relația Profesor-Elev în Lecția de Educație Fizică}

${ }^{1}$ Universitatea „Vasile Alecsandri” din Bacău, Calea Mărășești 157, 600115, România

Cuvinte cheie: profesor, elev, relații psihosociale, lecție de educatie fizica

\section{Rezumat}

Cunoaşterea şi reglarea relaţiilor psiho-sociale din cadrul grupurilor sportive ar trebui să constituie o preocupare permanentă a celor ce urmăresc să obţină performanța (antrenori, profesori, psihologi, staff tehnic ş.a.), prin exploatarea tuturor factorilor ce concură la obţinerea acesteia.Am abordat aceasta temă deoarece considerăm că relaţiile instituite intre elevi pe de o parte si intre profesor si elevi pe de alta parte, din cadrul colectivului de elevi si a echipelor sportive reprezentative, sunt deosebit de complexe şi insuficient studiate. Pornind de la situaţiile dramatice, conflictuale identificate, se pot concepe, regiza şi aplica în practică (la masa de lucru sau direct pe teren) o serie de acţiuni stresante şi/sau acţiuni cu încărcare emoţională, prin care să se încerce reducerea tensiunilor, diminuarea conflictelor şi reechilibrarea construcţiei psihosociale a colectivului clasei sau echipelor de jocuri sportive reprezentative a școlii.

\section{Introducere}

Profesorul de educaţie fizică trebuie sa aibă capacitatea de a şti să se stăpânească, de a aştepta şi a întârzia în unele hotărâri care pot sa violenteze ființa umană, necesitatea de a avea încredere în forţele proprii şi deosebită încredere în forţele celor pe care-i educă (Mitra \& Dragoş, 1980).

Cunoaşterea şi reglarea relaţiilor psiho-sociale din cadrul grupurilor sportive ar trebui să constituie o preocupare permanentă a celor ce urmăresc să obţină performanţa (antrenori, profesori, psihologi, staff tehnic ş.a.), prin exploatarea tuturor factorilor ce concură la obţinerea acesteia. Pe măsura dezvoltării sportului de performanţă şi a creşterii exigenţelor pe plan mondial, factorii psihologic şi social au devenit tot mai importanţi.

Relaţiile interpersonale sunt extrem de numeroase şi variate. Când persoanele interacţionează, fiecare dintre ele controlează un anumit segment din activitatea 
celuilalt (Newcomb, Turner, \& Conners, 1965).

Componenta biologică constă în înzestrarea fiziologică şi somatică a sportivului, cea psihologică reprezintă personalitatea cu aspiraţii, voinţăă, autocontrol, creativitate, idealuri, iar cea socială este legată de educaţie, cultură şi relaţii interumane. Nivelurile de performanță și satisfacție depind de coeziunea grupului (de elevi și antrenori), impunându-se cunoașterea aprofundată a nuanțelor psihocomportamentale (Ștefan, 2005).

În jocurile sportive, colaborarea şi rivalitatea (elevilor) capătă dimensiuni diferite faţă de sporturile individuale , deoarece - în cadrul echipei, care nu reprezintă doar suma aritmetică a indivizilor care o compun, interrelaţiile nu sunt întotdeauna coordonate sinergic (Nicu, 1993).

Personalitatea elevilor este identificabilă prin prezenţa ei şi eficienţa caracteristică pentru un anumit moment. Prin analiză psihologică îi surprindem dimensiunea, amploarea, durata în timp, eficacitatea practică în procesul adaptării la efortul din timpul lectiei de educatie fizica sau in antrenamente in cazul echipelor reprezentative sportive.

Toate acestea aparţin unui elev/sportiv (concret) şi deci sunt inseparabile de persoana lui (personalitatea) care ocupă un anume loc în cadrul performanţei sportive. Fenomenele surprinse, factorii de personalitate studiaţi, constituie trăiri personale nemijlocite ale sportivului studiat. Capacitatea de performanţă a echipelor de jocuri sportive poate fi crescută dacă alături de creşterea performanţelor fizice ale sportivilor, mărirea rezistenţei la efort, scheme şi strategii de joc originale, vom ţine cont de sintalitatea colectivelor de jucători.

Fiecare jucător reprezintă o personalitate, iar sudarea unei echipe înseamnă stabilirea unor conexiuni între personalităţile jucătorilor care compun echipa (Lupu, 2010). Iată o dimensiune nouă, puţin studiată şi puţin aplicată, în jocurile sportive de echipe.

\section{Material şi metode}

Scopul prezentei lucrări de cercetare este acela de a identifica relaţiile interpersonale din cadrul colectivului de elevi si/sau echipelor de jocuri sportive reprezentative, precum şi a posibilităţilor de ameliorare a lor, în vederea optimizării eficienței lecției de educație fizica sau creşterii dorintei de victorie si emulație.

Ipoteza cercetării poate fi enunțată astfel: cunoasterea relatiilor psihosociale dintre elevi, pe de o parte și elevi-profesor pe de altă parte poate optimiza sentimentele de simpatie și încredere reciprocă în detrimentul celor de antipatie, neîncredere și indiferență.

Studiul s-a desfăşurat în perioada noiembrie 2014 - mai 2015 și a implicat colective de elevi de gimnaziu din cadrul Colegiului Național „Nicu Ganea” din Fălticeni și colaborarea cu cadre didactice, din care amintim: Prof. Mihaela Togoe - CSA „Steaua” București, Prof.gr.I. Vasile Avramia - CN. „Nicu Ganea” din Fălticeni, Prof.gr.I. Ciocan Ionel - CN „Nicu Ganea” din Fălticeni

Pentru realizarea efectivă a acestui studiu a fost implicat colectivul clasei a VI-a B din cadrul Colegiului Naţional „Nicu Ganea” din Fălticeni. 
Relaţiile interpersonale dintre elevi în timpul orelor de educaţie fizică au fost cercetate şi interpretate în lumina sociometriei.

Pentru investigarea relaţiilor psihosociale, am selectat componenta masculină a clasei a VI-a şi am aplicat Chestionarul sociometric (Colibaba-Evuleţ \& Bota, 1998), cu 14 itemi, prin care s-a determinat: amplasamentul, statutul unui elev în câmpul relaţiilor interpersonale (lider, popular, izolat, ignorat, respins, etc.); structura psihosocială globală a colectivului clasei şi a subgrupurilor din cadrul său; diversele centre de influenţă; percepţia clasei faţă de un anumit membru; coeziunea de grup, etc., și Chestionar privind relațiile de simpatie/antipatie față de cadrul didactic precum și posibilități de îmbunătățire a lecției de educație fizică.

\section{Rezultate și discuții}

Înregistrarea opţiunilor s-a făcut într-un tabel cu dublă intrare (sociomatrice), în care elevii au fost notaţi pe verticală şi pe orizontală, iar relaţiile dintre ei cu (+) pentru atracţii şi (-) pentru respingeri. Pentru alcătuirea sociomatricei s-au luat în calcul răspunsurile la întrebările 1-7 din chestionarul I, referitoare la preferinţele şi respingerile fiecărui elev.

Tabel 1. Sociomatricea grupului de băieți - clasa a VI-a B

\begin{tabular}{llllllllllllll}
\hline & A.I & A.R & B.N & E.F & L.A & M.G & O.I & P.A & P.V & R.R & S.F & U.M & Z.G \\
\hline A.I. & & -1 & +1 & & -2 & & +2 & -2 & & $+1-2$ & -1 & -1 & \\
A.R. & -2 & & & +2 & +1 & +1 & +2 & -2 & +1 & -2 & +1 & -2 & \\
B.N & +2 & -1 & & +1 & -2 & +2 & +2 & -2 & & -1 & & -1 & \\
E.F & & -3 & & & -1 & -1 & +3 & -2 & +1 & $-1+1$ & & -1 & \\
L.A & & -3 & & +2 & & +1 & +1 & -3 & +1 & +1 & & -3 & \\
M.G & -1 & -2 & -1 & +2 & & & +3 & & -1 & +1 & -1 & -3 & \\
O.I & & -1 & +2 & & -1 & +1 & & -3 & -1 & $+1-2$ & & -1 & \\
P.A & -1 & -1 & & +1 & -2 & +3 & +2 & & & $+1-1$ & & & \\
P.V & -1 & -1 & & +1 & -2 & & +2 & & & $+1-2$ & +1 & -2 & \\
R.R & & -3 & & +1 & & & +3 & & & & -3 & -3 & \\
S.F & & -2 & & -2 & & +1 & +2 & -1 & +1 & -1 & & -1 & -2 \\
U.M & -1 & -1 & & +2 & -2 & +1 & +1 & & & & & & \\
Z.G & -1 & & -2 & & -2 & +1 & +3 & -2 & & & -2 & +1 & \\
\hline
\end{tabular}

Pe baza sociogramei de mai sus, am construit un tabel centralizator, care conține numărul de atracții/respingeri pentru fiecare elev în parte.

După cum se observă din sociomatricea centralizatoare prezentată, la nivelul elevilor de sex masculin din clasa a VI-a B avem: elevi pentru care s-au înregistrat doar relaţii de atracţie (fără a se înregistra respingeri): O.I; elevi pentru care s-au înregistrat doar relaţii de respingere (fără a se înregistra atracţii): A.R, PA, Z.G; elevi pentru care s-au înregistrat un număr mai mare de atracţii şi un număr mai mic de respingeri: EF, M.G.; elevi pentru care s-au înregistrat un număr mai mic de atracţii şi un număr mai mare de respingeri sunt A.I., L.A., U.M; elevi la care numărul de atracţii a fost egal cu cel de respingeri: B.N. 
Tabel 2. Matricea centralizatoare a atracțiilor și respingerilor

\begin{tabular}{cccc}
\hline Nume & Atracții(A) & Respingeri(R) & Total(A-R) \\
\hline A.I. & 2 & 7 & -5 \\
A.R. & 0 & 19 & -19 \\
B.N & 3 & 3 & 0 \\
E.F & 12 & 2 & 10 \\
L.A & 1 & 14 & -13 \\
M.G & 11 & 1 & 10 \\
O.I & 26 & 0 & 26 \\
P.A & 0 & 17 & -17 \\
P.V & 4 & 2 & 2 \\
R.R & 2 & 7 & -5 \\
S.F & 2 & 7 & -5 \\
U.M & 1 & 18 & -17 \\
Z.G. & 0 & 2 & -2 \\
Total & $\mathbf{6 4}$ & $\mathbf{9 9}$ & $-\mathbf{3 5}$ \\
\hline
\end{tabular}

Informaţiile oferite de testul sociometric sunt foarte importante pentru profesor. Pe baza lor se poate realiza orientarea pozitivă a relaţiilor dintre elevi, se pot explica tensiunile latente sau manifestate între ei, se pot converti relaţiile negative în relaţii pozitive cu valenţe educativ-formative.

Din prezentarea datelor de mai sus rezultă că în cadrul elevilor masculini există simpatii şi antipatii reciproce, către unii dintre subiecţi se îndreaptă atracţia majorităţii celorlalţi iar unii subiecţi sunt respinşi de majoritatea colegilor.

O primă concluzie care se remarcă analizând sociomatricile de mai sus este aceea că la nivelul grupei de băieți există per ansmablu, o stare animozitate, o situație tensionantă, întrucât numărul de respingeri este mai mare decât numărul de atracții (64 atracții, 99 de respingeri), lucru ce poate determina efecte negative în obţinerea rezultatelor dorite.

Conform sociogramelor, în cadrul grupei de băieți se evidenţiază un lider informal absolut - O.I. (26 atracții, 0 respingeri)

În cadrul grupei de băieți nu există nici un elev care să fie izolat (nu votează şi nu este votat), dar putem afirma că există 5 elevi toleraţi: A.R., P.A, Z.G, L.A., U.M., primii trei neprimind nici un vot pozitiv, iar următorii doi primind câte un singur vor pozitiv. Votaţi cu cele mai multe respingeri sunt elevii A.R., U.M., P.A.

Coeziunea clasei de elevi constituie un obiectiv important al profesorului. Elevii formează un colectiv unitar atunci când aceștia sunt animați de dorinţa şi bucuria efortului în comun, când se concentrează pe realizarea sarcinilor comune, și decid împreună asupra problemelor clasei.

La Chestionarul II, întrebarea 1 - Ce calități apreciați în mod deosebit la profesorul de educație fizică - răspunsurile au fost reprezentate grafic în figura 1 .

Se observă că majoritatea răspunsurilor $(55 \%)$ se repartizează în mod oarecum egal între atracția către ludic a profesorului (29\%) și aptitudinea de bun 
organizator / iniţiator de evenimente (26\%), ceea ce este explicabil prin particularitățile de vârstă ale elevilor de clasa a VI-a.

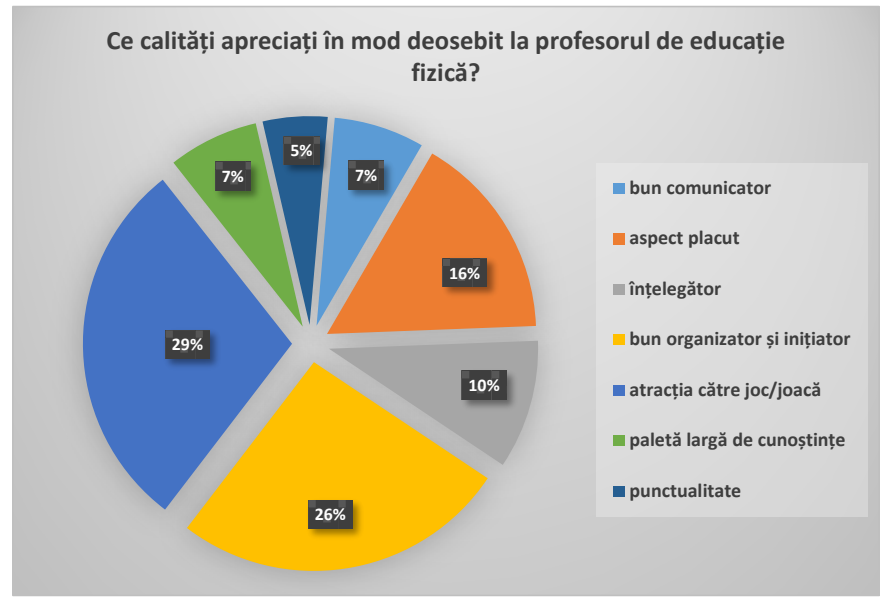

Figura 1. Calități apreciate de elevi la profesorul de educație fizică

La întrebarea 4 - Cum apreciați relația dvs. cu profesorul de educație fizică majoritatea elevilor (68\%) apreciază ca bună relaționarea cu profesorul, 18\% o apreciază ca proastă, iar restul de $14 \%$ este distribuit pe extreme (foarte proastă/foarte bună) în mod egal.

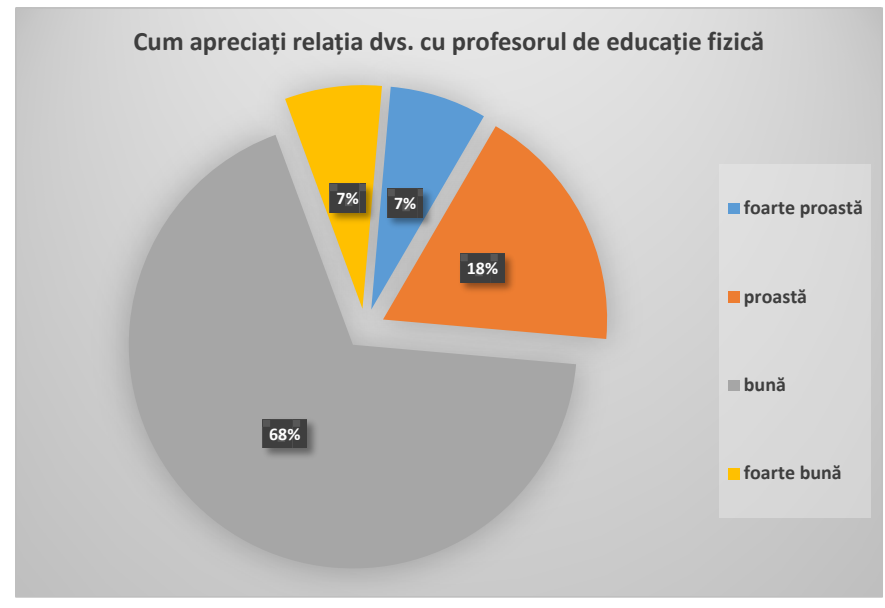

Figura 2. Relația profesor - elevi

Întrebarea 5 - Care este relația dumneavoastră cu colegii in timpul orei

Din analiza datelor centralizate şi din figura 3, se desprinde aceeași concluzie, desprinsă analitic din aplicarea chestionarului I și interpretarea sociogramei, și anume că la nivelul clasei nu există o relaţionare bună între elevi. 


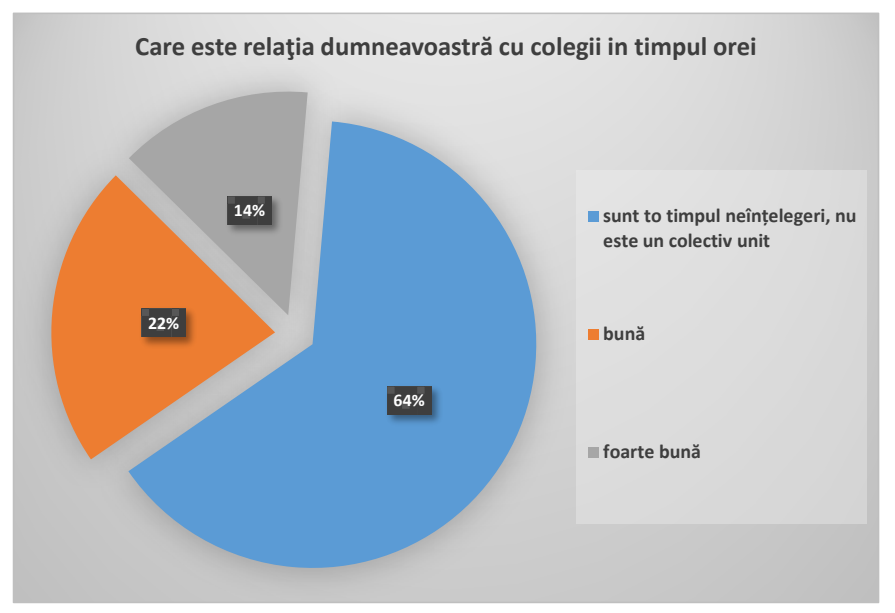

Figura 3. Relațiile interpersonale - elevii clasei a VI-a B

La întrebarea 10 - Ce tip de conducere preferaţi din partea profesorului de educație fizică - aproximativ jumătate dintre elevii chestionați s-au declarat în favoarea unui tip de conducere laissez-faire (56\%), 36\% doresc o conducere democrată, iar restul o conducere autocrată.

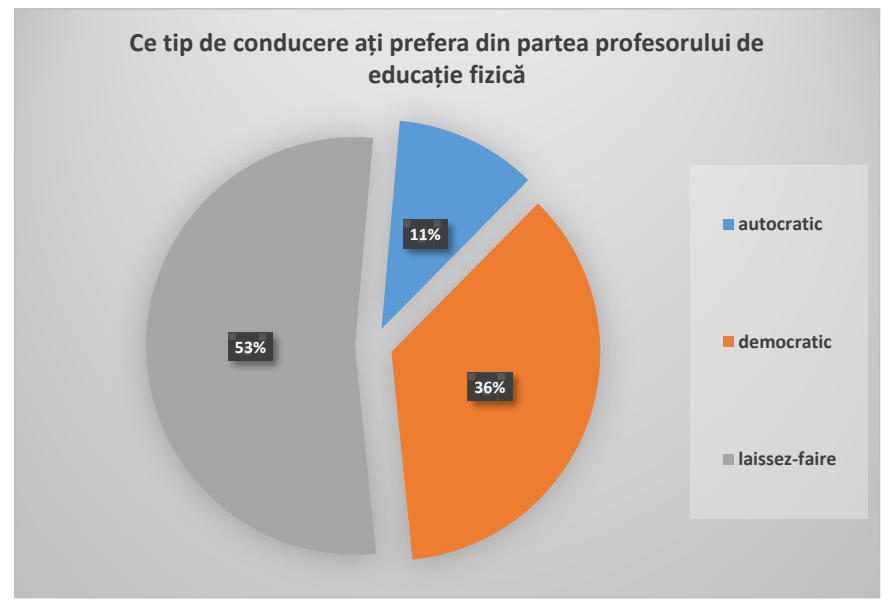

Figura 4. Tipuri de conducere preferate de elevi

\section{Discuții}

În activitatea sportivă, relaţiile preferenţiale sunt de două feluri (evidenţiate de Rioux \& Chappuis (1999), citaţi de Epuran, 2005): afective şi operaţionale.

Pentru a facilita rezolvarea problemelor disciplinare, profesorul se poate implica în situaţia elevului, poate să-şi exprime preocuparea pentru elev în calitate de persoană, construind astfel o relaţie cu elevul. În felul acesta, profesorul poate să-şi ajute elevii să reflecteze asupra propriilor dorinţe şi planuri, încercând 
totodată să înţeleagă opţiunile acestora. În cazul în care elevul a făcut o alegere iresponsabilă, profesorul îl poate întreba: „Ce doreşti de fapt?” „, Ce îţi trebuie?” „, Cum ai vrea să fie la şcoală?”

Relaţia profesor - elev reprezintă modalitatea principală de mediere didactică, de transpunere a acesteia într-o variantă umană, subiectivă. Dincolo de conţinuturile concrete care se transmit, în activitatea didactică va fi important foarte mult tipul de interacţiune care se va statornici între clasa de elevi şi profesor, precum şi atitudinea acestuia în a se relaţiona ca grup şi la fiecare elev în parte.

Relaţiile profesor-elev pot fi caracterizate prin dimensiuni precum: conflictul, apropierea şi dependenţa excesivă. Acestea se află într-o strânsă legătură cu alte variabile precum: vârsta, etnia, statutul social.

Prea multă expunere din partea profesorului de educaţie fizică poate fi jenantă, iar prea puţină ,îngheaţă’ relaţiile cu ceilalţi (Pop, 2009).

\section{Concluzii}

Datorită caracterului distinct al orei de educație fizică faţă de alte discipline, se pot și este necesar a se măsura relațiile interpersonale în cadrul colectivului în vederea identificării unui lider, mediator între cadrul didactic și colectiv care de multe ori nu coincide cu, șeful clasei”.

Ipoteza noastră se confirmă în sensul în care cunoașterea climatului psihosocial al colectivului contează în gestionarea relaţiilor profesor de educație fizică și elev prin aceea că ajută la stimularea elevului în depășirea propriilor limite, în acceptarea partenerilor de echipă, în dorința de victorie sau acceptarea înfrângerii, în stimularea spiritului fair-play. 